\title{
The Luso-Baroque Republic of Things and the Contingency of Contact
}

\author{
Mia M. Mochizuki \\ New York University, Abu Dhabi \\ Institute of Fine Arts, New York
}

\begin{abstract}
The Republic of Letters is an established concept in the early modern world, but the corresponding circulation of material things, from coins to all they could purchase, has been less recognized, despite its acute agency in the move from an intra-regional Europe to global systems of trade, politics and religion. By tracing the visual patois of a single subject, Our Lady of the Immaculate Conception, through its appearance in multiple media along the Portuguese eastern trade route (Antwerp, Lisbon, Goa, Nagasaki), this paper draws upon the tangible residue of engagement to consider how the active responses sparked by mimesis can pave the way for a hermeneutic of cultural exchange grounded in the contingency of contact zones.
\end{abstract}

Keywords: Baroque art, Republic of Things, social lives of things, global circulation, mimesis, contingency.

\author{
"Novos mundos ao mundo irão mostrando." \\ (Camões, Os Lusíadas 2: 45)
}

\section{Coining communication}

A small coin, an object that fits easily in one's palm, seems an unlikely instrument by which to grasp the sixteenth-century world (Fig. 1). With the Virgin of the Immaculate Conception on one side, and the royal arms on the cross of Christ on the other, this small coin minted for João IV of Portugal functioned like a portable padrão, the stone cross standard with the Portuguese coat of arms used to 


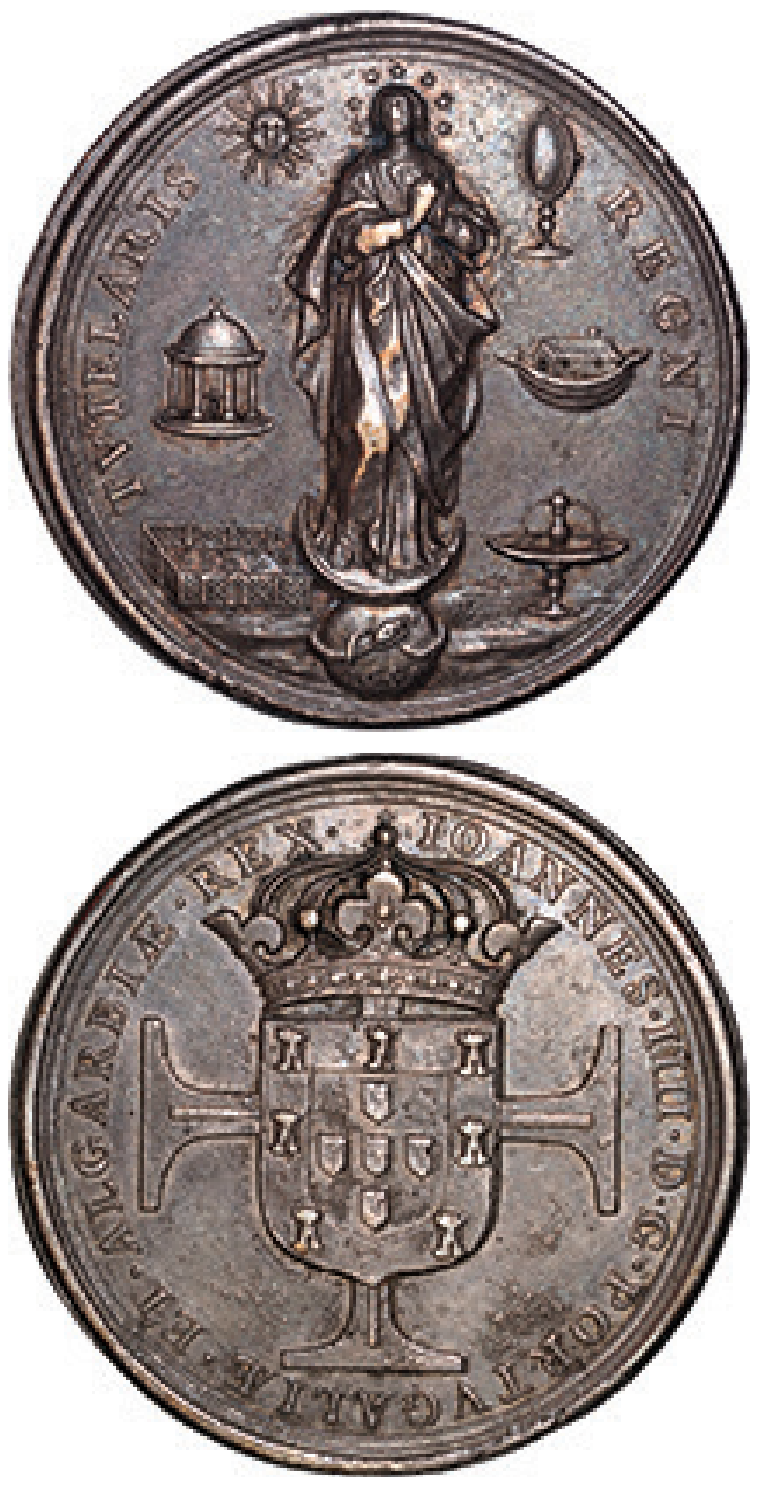

Fig. 1. Anonymous, Coin of King João IV with Our Lady of the Immaculate Conception and Royal Arms on the Cross of Christ, c. 1648-1650, bronze. Lisbon, Imprensa Nacional-Casa da Moeda (photo: Manuel Farinha/INCM)

Please note all images in this article have been reproduced at the low resolution Internet standard (72 dpi) per the request of copyright holders. 
mark the realm's imperial and soteriological claims, a sign of hand delivery in a circuit that would amount to an informal Luso-Baroque Republic of Things.

Much has been made of the heavily hyphenated Luso-Afro-AmericoAsian Baroque, and the provisional solution of naming a Lusophone Baroque for areas where Portuguese was the language of cultural and mercantile exchange was a constructive development for connecting disparate countries, interests and languages when sovereignty was not viable in foreign lands. After all, Portuguese quickly became the lingua franca of the networks along the Portuguese eastern trade route and the overlapping Jesuit East Indies mission, causing even Francis Xavier to write from the diocese of São Tomé de Meliapor: "If there are some foreigners in our Company [i.e., the Society of Jesus] who cannot speak Portuguese, they must learn it, because otherwise there is no interpreter to understand them" (Mendes de Almeida 224). The "black ships" (kurofune) along this route sailed under the Portuguese flag, and by far the largest group of Jesuit missionaries heading overseas were Portuguese, even if there were also Italians, Germans, Spaniards, Austrians, Englishmen, and a few Poles, among others (Alden 632). The result was an unusual historical moment when Portuguese was the dominant language of communication along the eastern trade route by dint of both bodily majority and pan-European diversity. But all recognize that despite this language's distinctive position, Portuguese was not always spoken in great quantities, and when it was, it bore its own baggage of preference, class, and fealty. So by employing the term "Luso-Baroque," cultural critics cite less a linguistic relationship than a recognition of the authorial organization and management of the networks of early modern contact zones, a matrix whose verbal ambiguities alone would thus seem to argue for the fruitfulness of exploring alternative media of communication.

The Republic of Letters is an established concept in the early modern world, but the corresponding circulation of material things, from coins to all they could purchase, has been less recognized, despite its acute agency in the move from an intra-regional Europe to global systems of trade, politics and religion, and the great opportunities offered for many voices to find expression, whether by design or by subverting original intention, rather than the concerns of a single culture's social and intellectual elite. Unlike a padrão, however, the 
visual culture of trade, of the coin, was optative, in process, not yet achieved, quite unlike the nineteenth-century narratives that have defined post-colonialism. It constituted an arena in which desires sparred for supremacy: João III's desire for commodities, Pope Gregory XIII's desire for converts, and the (later) shogun Tokugawa Ieyasu's desire for consolidated power in Japan. Copying, conversion and colonialism, or more appropriately for the sixteenth century, a growing consciousness of world, shared a foundation in the principle of likeness achieved through profound imitation. And nowhere was this more true than when the printing press used its iconographical dominance to stake its mimetic claims-or impressions-on the world.

I use the word "impressions" specifically to reference the technology of image production in the many objects implicated by the printing press, whether coin or playing card, book or print, sculpted or painted copy, and the dynamic reactions they engendered when the morphology of imitation was placed in the context of global initiatives for trade and conversion. A seemingly innocuous object could thus harbor impressions - the coin of communication - when the printing press and the alterity of encounter challenged the concept of pictorial mimesis. Art history has tended to look to mimesis as naturalistic representation, the process of imitation or even mimicry (Dalwood, et al.). But anthropologists such as Michael Taussig have reminded us that mimesis further comprises receptivity, response, and particularly actions that oscillate between modes of appropriation and pushing against received norms in ways that bear significant political consequences. It is, however, neither enough to note this type of image fabrication, nor to trace its sources, as art historians are wont to do. The responses to western modes of naturalism are just as critical a part of the mimetic canon. And they were as culturally determined as they were employed for their own ends. When John K.G. Shearman famously urged art historians to "Only connect..." in the A.W. Mellon Lectures of 1988, he repositioned Renaissance art history to take into account the integral role of the spectator in the design of Italian painting and sculpture. Now over two decades later, European art can be reconnected to its early global context, thereby expanding reception theory to include its many willing and hostile audiences around the world. Further still, object connectivity links not only supply and demand, not 
only the many worlds encountered from port to port along lengthy overseas voyages, but it also implicates the many contacts within one society, complicating the traditional relationship between artist and viewer or patron in hand-tohand negotiations.

In this short space, even tracking just one visual vernacular popular along the Portuguese trade routes, like the flip side of Portuguese imperial desire seen in the coined impression of Our Lady of the Immaculate Conception, underscores the somatic experience of the thinghood of objects in the Lusophone Baroque. At a time when theories of vision relied upon the "touch" of the eye's gaze, grasping the circulating coin provided some sense of catching hold of, only just connecting, with the intangible unknown abroad. In the well-trawled annals of exchange, the metaphorical elephant placed in a dark house, known from a parable on the limits of human understanding told by the thirteenth-century Sufi poet Jalāl ad-Dīn Muhammad Rūmī (or Jalāl ad-Dīn Muhammad Balkhī) in his Masnavi (Arberry 16, 207-08), was as important as the actual specimen, "Suleiman," who traveled from the King of Ceylon to João III in Portugal, before being re-gifted to Archduke Maximilian II of Austria (Levenson 109; Kinoshita 39-40). By touching the elephant, Rūmī demonstrated how each visitor was able to draw a discrete nugget of fragmentary knowledge by a familial relationship with shape. So the feel of the elephant's trunk evoked a waterspout, the ear a fan, the leg a pillar and its back a throne. Each graze, each stroke of exploratory handling was correct as far as it went, if the totality remained elusive, in what we might consider to be an apt allegory for an early modern European attempt to come to terms with a radically changing world by means of the physicality of handwork.

\section{Imprinting an idea}

In the "worlding" of a visual idea, João IV's coin relied upon an idiom found in a much-copied design by Johannes Stradanus (1523-1605) (Fig. 2). Stradanus is known to have completed as many as seventeen versions of Our Lady of the Immaculate Conception, both with and without the symbols of the Laurentian Litany, that were circulated by Flemish engravers like the Collaerts, Galles, and Wierixes. ${ }^{2}$ We can well imagine the exertion required to turn the screw, 


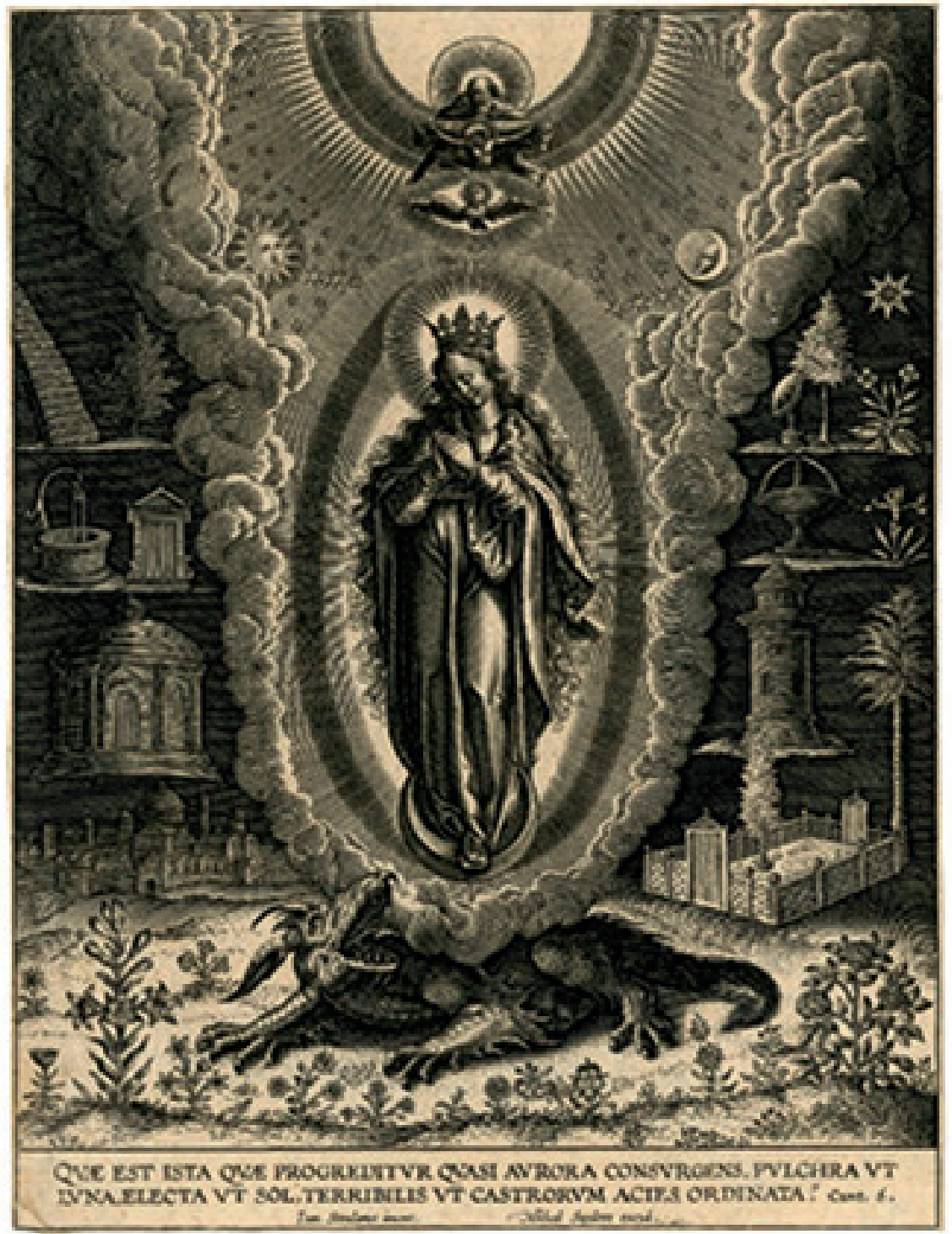

Fig. 2. Johannes Stradanus, Our Lady of the Immaculate Conception with the Symbols of the Laurentian Litany, after c. 1611, engraving. London, British Museum 
the damp paper molded around cast metal letters, in order to brand by ink in any one of the Antwerp printing houses where such prints originated. In fact, early printing's emphasis on a touch-based ideal of mimetic Christian production was as revolutionary as it was deeply traditional, with antecedents in the core justification for western religious realism, the acheiropoieton, or myth of the miraculous image made "without human hands." This was the desire to preserve identical copying "as best I can," when Jan van Eyck co-opted mimesis to validate the devotional image's truth claims, an illusion that would be cast as increasingly complex and troubled as it flickered between canvas painting and veil, contact relic and image very much made with human hands, a call to sight and a testimony to the power of touch for picture-making. And printing also drew upon this pictorial tradition to use the intimacy of physical pressing to replicate its own identical imagery while inadvertently betraying a visual record of iconographical intention, even without the specifics of precise antecedents. Through the handling of the press, images like Stradanus' Virgin of the Immaculate Conception provided the baseline broadside for the worldwide broadcasting of a concept.

This message was cultivated in Europe, where due to a specific cultural framework of associations, Our Lady of the Immaculate Conception enjoyed a distinct popularity in both post-Tridentine visual culture at large and Portugal in particular as this subject began to replace Assumption and Coronation of the Virgin iconography (Reau 457-65). By the seventeenth century, the crowned majesty of the Queen of Heaven with the infant Jesus in her arms was downplayed in favor of a humble prayer gesture with the ring of stars of the apocalyptic Virgin of Revelation 12: 1-2. ${ }^{3}$ Furthermore, the crescent moon and globe of yore that functioned as her dais and rationale tended to be reinterpreted as a triumph of the Christian cross over the Muslim crescent in light of decisive, traumatic wars such as the Battle of Lepanto. The reformatting of the Virgin's iconography for the global battle with heretics along the lines of a divine maternal figure watching over the recently expanded skies resulted in her gracing numerous altars, altarpieces and oratories both at home in Portugal and abroad as merchants ventured further afield (Dias, História 1: 265). After the restoration of Portuguese independence in 1640, João IV would even appoint Our 
Lady of the Immaculate Conception as a patron saint of the realm and thus his choice for a global currency.

Perhaps even more significantly, like the trail of a radioactive spore, this message illuminates the trajectories, the by-ways of meaning, of the implicit, entangled webs Our Lady traversed. As a print used to inspire the design for a coin, a vivid pictorialization of the process of a material emissary moving abroad from the busy port of Lisbon, the Our Lady of the Immaculate Conception engraving presents itself as a signal, card-carrying extract from the physical corpus of a "seen network" (retia mirabilia)(Latour 220; Greenblatt, Marvelous Possessions 1-25). Even long before setting sail from Europe, the permeability of Portugal's artistic borders was already fairly well established, with first Flemish (at least through João III's reign), then Italian, later French and periodically Spanish influences of varying degrees of intensity. ${ }^{4}$ Court contacts with the Netherlands dating back to the time of João I inaugurated a flurry of artistic exchange with the many Flemish representatives of Madeira's sugar trade (Dias, "Influência" 26-28). These long-standing Luso-Flemish trade interests, for cloth, works of art, weapons and harnesses, led the Portuguese court to establish feitorias, or trading bases, in the Southern Netherlands, first in Bruges before 1390, and succeeded by Antwerp by the beginning of the sixteenth century (Born and Martens; Gijsen). More akin to a cross between a trading base and an embassy, the feitoria in the Southern Netherlands was where the royal family, noble and ecclesiastical dignitaries, and merchants and artists would lodge, meet, and haggle. Beginning in 1523, the cosmopolitan humanist Damião de Góis (1502-1574) presided over the Antwerp feitoria, and it was there that he wrote some of his most famous tracts on Ethiopian Christianity, such as the Portuguese translation of the "Letter of Prester John" (found in the eighth book of his Chronica del rei D. Manuel) written by the Ethiopian Queen Eleni in 1509, and the Fides, religio, moresque Aethiopum (1540). Besides his textual output, Góis also managed to put together a serious collection of Netherlandish religious art during his stay (Markl, "Lart dans la défense" 192-96). The residence of the Portuguese factors and consuls in Antwerp, called the Casa de Portugal, was near the Church of St. James in Kipdorp on the very same street where many painters had their workshops (Martens 69-71). By 1525, the 
Feitoria de Flandes was responsible for about twenty-five percent of all income for the Casa da India in Lisbon (Born and Martens 155, 373). And circumstantial evidence relates, for example, that just in the year 1553, ships left the port of Antwerp for the Iberian Peninsula (Spain, Portugal, and the Canary Islands) with a trunk of crucifixes, four trunks and three casks of sculptures of the Christ Child, a smaller cask with a range of devotional images, fourteen paintings (each valued at ten to fourteen libras), and a painted altarpiece worth forty-five libras (Dias, "Influência" 27-28; Gijsen 302-03).

Even given the sparse hints of parameters, it is difficult to overstate the importance of Flemish engravings like Stradanus's Our Lady of the Immaculate Conception and Italo-Flemish print traffic in sixteenth-and seventeenth-century Portugal. ${ }^{5}$ What began with close commercial relations, such as with the celebrated publisher Christopher Plantin in Antwerp in 1566, especially busy after the selection of Pierre Moerrenfort, brother of Jan Moretus, to serve as his agent in Lisbon (1570-1577), was continued with the establishment of offices for many Antwerp printing houses in Lisbon, like that of Pedro van Craesbeeck in 1590, only to be further stimulated by the commissioning of Flemish agents to promote Portuguese interests in absentia (Sobral 57; D’Alcocheyte; Peixoto 184). The staggering numbers are preserved in inventories. In 1633, one André dos Santos, an art merchant with a shop in Lisbon, would order through his contact in Antwerp, Paul du Jon, two boxes of prints bearing over 14,400 objects, including individual folio pages, books and illuminated sheets of parchment, with a follow-up order of another 2,020 unspecified prints in the same year (Huylebrouck; Serrão 184-85). Not only are the quantities remarkable, but the itemization of objects also reveals the level of knowledge and degree of specificity of the trade. Objects were not simply described by artist name, such as Bolswert, Blomaert, and Rubens, or subject matter, such as a life of St. Augustine, crucifixion, Regina coeli (a name often used at the time to describe the Madonna Salus Populi Romani), Ecce Homo, Flagellation, Conversion of St. Paul, Judgment of Salomon, or simply hermits, as well as secular subjects, like landscapes or animals; they were also characterized by value, size, material (i.e. paper or parchment), technique (colored or not), and new invention or copy, indicating a fairly sophisticated level of engagement. 
With its dedication to looking outwards, whether over land and channels to Northern Europe or across seas to Africa and Brazil, the art of the Portuguese court relied upon crossing established boundaries. By the end of the sixteenth century, the intra-European networks that yielded the main flow of Luso-Flemish objects at the Portuguese courts, like the Joanine and Manueline Portuguese styles, were mapped on to global expansion, to produce a circulating Republic of Things in what we might term the "Luso-Exchange" of western-organized workshops scattered along the Portuguese eastern trade route from Lisbon to Goa, Malacca to Macau and Nagasaki. Unlike today, copying in the early modern world, like that of coin from print, was less a demonstration of proximity to an original than a virtuoso cross-section of a hive of entangled connections, notable for the incongruous disproportion of its relationships, that the limited technologies of the sixteenth century required when surmounting great distances overseas. When iconography sailed headlong into the global context of world, it was more essential than ever to take objectivity at its word, as the totality of objecthood with meaning lodged in a thing's content, but also in its form, material, function and context. When European art was propelled east by a sea of overlapping webs, not only letters, but also objects, cloth, spices, precious metals, and gemstones constructed a matrix of inherent recursivity, a network whose efficacy lay in its ability to reflect on itself, a system that created and continued to recreate itself as spontaneous, collective and internally generating the effects of its own reality by productively commenting on the dominant sensation of a rootedness bound up with desires many worlds away (Riles 3, 6, 172-73).

\section{Chiseling Local Roots}

After the initial burrowing of the burin into copper plate, the popular Our Lady of the Immaculate Conception began to appear around the world, each time assuming an on-site iteration: a classically western subject matter laying local roots, where the global confronted the regional in contact zones like Goa. There, for example, an Indo-Portuguese artist harvested regionally sourced materials such as ivory to carve details into a small figurine with his own vernacular flourish for textile decoration, or for the evocation of clouds (Fig. 3). 


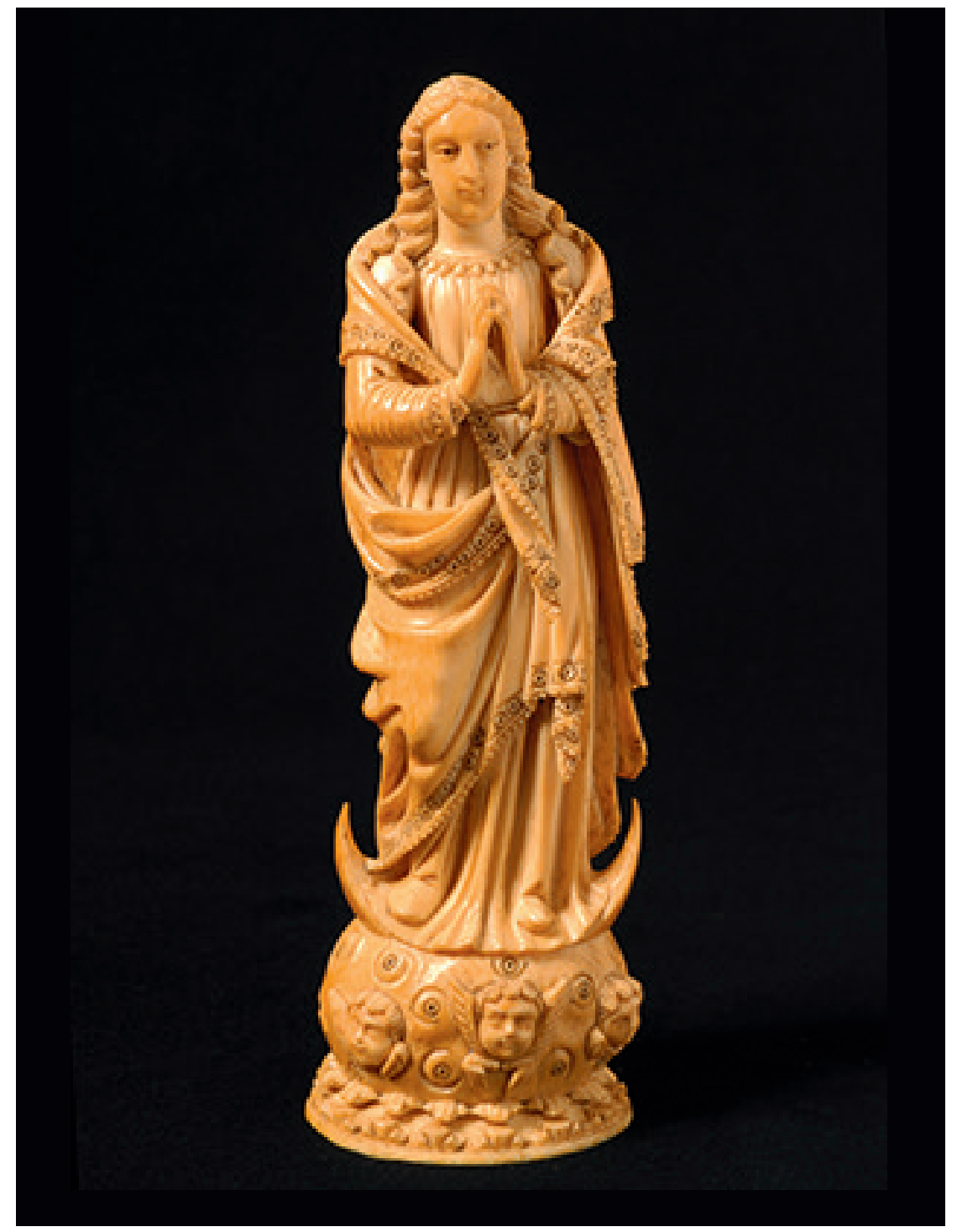

Fig. 3. Indo-Portuguese Artist, Our Lady of the Immaculate Conception, $17^{\text {th }}-18^{\text {th }}$ century, ivory. Lisbon, Museu de São Roque / Santa Casa da Misericórdia de Lisboa (photo: Júlio Marques) 
With her frontal, symmetrical pose, stylized dot-in-circle pattern along the borders of her cloak, and sharply incised cloud curls alternating with cherubim on the spherical base, this Our Lady of the Immaculate Conception had traveled far from her traditional representation before she returned to Europe to enter the collection of the Santa Casa Misericórdia de Lisboa/Museu de São Roque (Lino, Silveira, and Marques 19-38; Oliveira, Morna, Simões, and Lino 117-18). ${ }^{6}$ In spite of the Virgin's virtual voyages, her message remained determinedly on point. In this, she followed the metaphorical molding of self into the contours of Christ as part of the wholesale investment in incarnational "like" representation, in the mode of Thomas à Kempis's early modern bestseller De imitatione Christi (c. 1418-1427) and closely followed by Jesuit texts such as Jan David's Veridicus christianus (1601), that underscored interior mirroring at the expense of outward semblance (Mochizuki, "Diaspora"). Gradually, as an outgrowth of both emphasis and circumstance, mimesis done and un-done became the double-sided heritage of the religious harvest of copying by touch, of imitative conversion in the face of expiration, that European printmaking unleashed on the world.

In its global circumnavigation, the thinghood of an object, such as the medium and the formal, stylistic patois of the artist (and even the occasional iconographical quirk, like a lotus-leaf pedestal for the Christ child), was a critical way in which the expanses traveled by an idea, the travel log of its conceptual diaspora, were stored. It was the trail of materials that cemented the eastern origin of a very western-style portable oratory of a Madonna and Child in Salem's Peabody Essex Museum (c. 1597), its oils painted on an Asian hardwood, possibly the padauk of South Asia, that has been attributed to the painting atelier of the Jesuit mission to Nagasaki. The materiality of an object became the pictorial equivalent of the "rootedness" that Stephen Greenblatt has noted was curiously fundamental to the mobility of early modern globalization, the register of the paradox that the global was only expressible, knowable, in the specific circumstances of a local environment (Greenblatt, "Mobility” 250-53). Nor was contact a single, finite event. Rather, flux was only compounded when objects drifted not simply West to East, Portugal to Japan, mono-directional and complete, but back and forth between Rome, Goa and Macau in a global 
diagram of urban contingency. Objects were caught in networks that prefaced dislocation in a paroxysm of being borrowed, distributed, and betrayed. When caravel connectors enabled a Western idea to be painted on a possibly Indian support in a workshop in Japan, objects such as these became encrustations of maritime motion, incubators of innovation, no different from the barnacles amassed at length on their hulls. Transportation, and the trading of visual and verbal information that resulted from it, ensured that global-local scaling was no longer viable when all were interconnected micro-worlds, no one place dominant enough to be worldly or self-contained enough to be truly mundane (Appadurai, Modernity 178-99; Latour 176, 192, 204).

The distinction was that some places, like Goa, had more connections than others in a flattening of the conceptual landscape that should better stress cables, links, nodes and the vehicles that move between them with their concurrent relational emphases on disjunction and conjunction. The multi-faceted and multi-directional home-grown moved, continuously redispatched and redistributed in a form of genesis more akin to cell division. Bruno Latour has preferred the inverted neologism of "work-net" for "network" to capture just this dynamism $(128-33,143,159,175)$, where change was the only constant in the emergence of European print production on a global stage, and Roland Greene has more recently characterized the world as an engine to underscore both its in-process conceptualization and its latent energy, its adamant refusal to fix, as one of the defining concepts of the age (143-72). What the fabric of the provisionally local makes visible is the role of the revised poetics required by the aggregation of place in the early modern world, and then not simply in one socio-historical context, famously termed the "period eye" by Michael Baxandall, but by doing justice to the many ports of call along the imagined communities of missionaries and merchants, letters and objects, spices, cloth and raw resources. We might call this a "mobile imaginary," which I do not employ to simply refer to a material culture on the move, but rather as a way to underscore the need for a much larger interpretative acceptance of the atomic potential in the life of the object, and vice versa, the imagination as a social, material practice (Appadurai, Modernity 31-33, Social Life of Things). In the media ecosystem of the visual enterprise, objects found their grammatical parallel in 
relational prepositions, their equal as traces of collective relations in the myriad webs of pre-object, object and quasi-object. Reframing iconography in a global context relies upon re-inserting the flow of things into the equation.

The connective tissue and open-ended mediation of an itinerant mentaliteitsgeschichte resulted not only in a passage or dissemination of impressions and things, but also a circulation of subjectivity that required reconstruction through a series of compounded layers, each distinct in its own right, that ultimately validated the telling detail, the bits and bytes, over the bulk (Latour). Subjectivity needed not be strictly interior, but could be caused by the detritus of marks left behind from external movement; mediators were not simply instigators, nor could vehicles be transported without any residual effect. We can look "outside" the object, to the context, for edification on those things "hidden" in the object, but the information we seek is better regarded as in-between, the ellipsis that requires coaxing to emerge clearly. No exchange relied on only a single place or time, nor was it composed of the same types or equal pressures, or for that matter, possessed components that were all visible in a single moment. Interaction was always a dauntingly messy enterprise, deeply dependent on the volatile concatenation of serendipitous happenstance across continents and oceans. The element of the random must be calculated, what Donald Norman has called the "gap of execution," or the space between intention and experience that art historians have long known to exist but have been hesitant to embrace with an analytic structure that factors in the unknown, the $\mathrm{x}$-factor, the improvisational. For criticism to plan accordingly, the life of the object must be accepted as much as a result of imaginative projection and contingent opportunity as a predictable, intentional outcome.

\section{Painting Agency}

By shifting interpretative emphasis to the vicissitudes of heavily trafficked contact zones in a process-oriented approach to production, the agency of individuals assumes center stage. In a delicate, postcard-size hanging scroll (kakemono) depiction of the Madonna of the Snow, Our Lady of the Immaculate Conception almost seems to don a costume, taking cover in Japanese colors and gold as a shape-shifter in metamorphosis (Fig. 4). Western-trained 


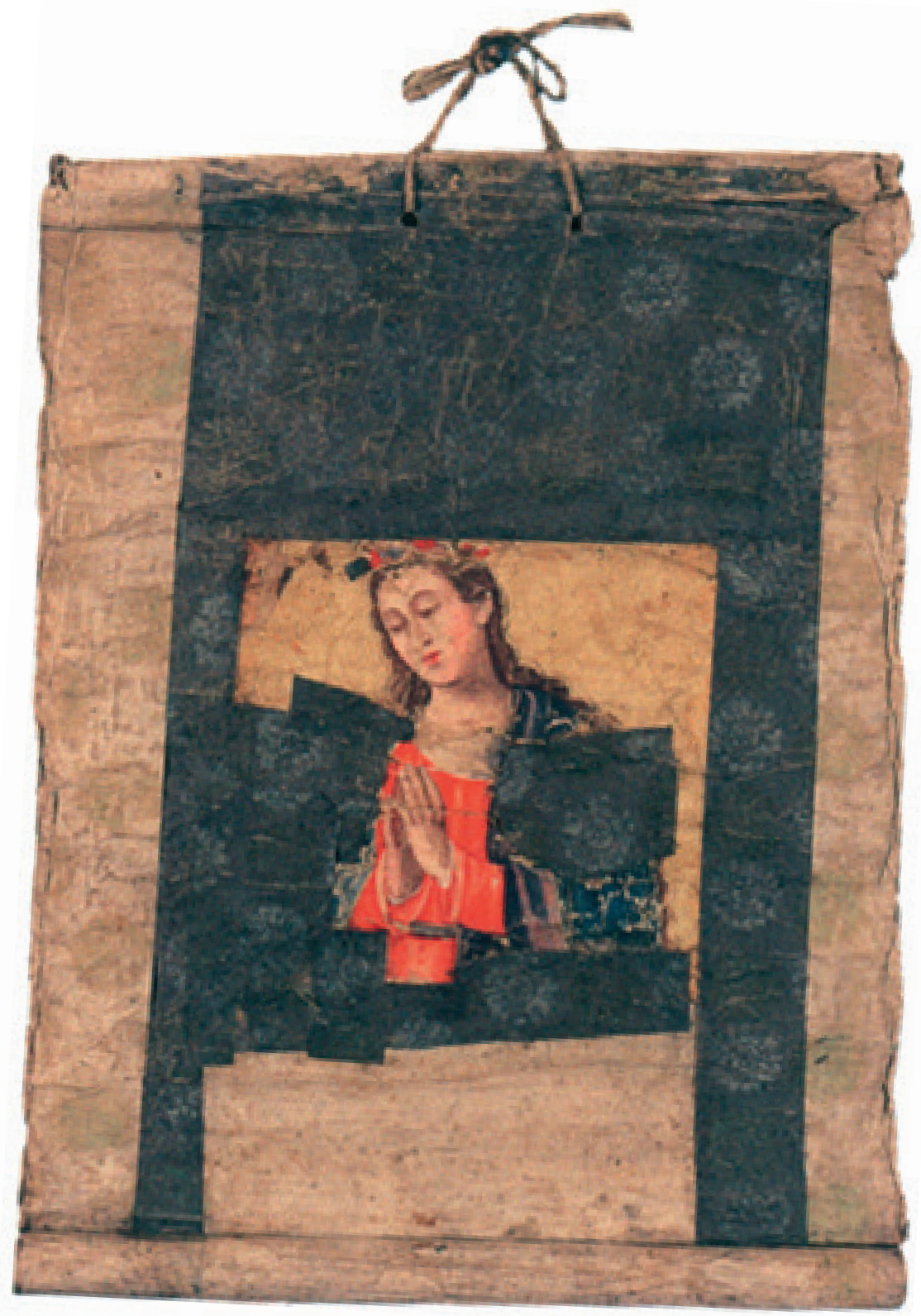

Fig. 4. Niccolò School, Madonna of the Snow, c. 1583-1614, Japanese colors and gold on paper, mounted on a hanging scroll. Nagasaki, Twenty-six Martyrs Museum 
Japanese artists in Br. Giovanni Niccolò, S.J's workshop in Nagasaki would buttress pictorial borrowings with elements from European Immaculate Conception and Assumption imagery, Annunciation and Sleeping Child iconography, drawing upon the viable options at hand to construct an image of a subject when no sources were available (Mochizuki, "Seductress of Site"). If retooling a European concept for the constraints of local markets was fairly straightforward in a "before" and "after" comparative model, multiple implicated locales suggest the frequent lack of a resident model or paradigm, particularly for less popular iconographies, was more typically a characteristic burden for a western Republic of Things abroad. Early modern paintings like the Madonna of the Snow are well suited to Jean-Luc Nancy's highlighting of the role of human relations and agency as the key to "world-forming," an idea that bears a particular resonance for objects in light of Alois Riegl's notion of Kunstwollen as a "will to form" (Late Roman; Problems). These peripheral, often ephemeral agents acted as a moving target for all the ideas, desires and objects swarming toward them. Coin, print, sculpture, painting and a host of other artifacts engaged along the way posited a visual sociology of associations and intimate a life of objects that hovered intriguingly between production and reception. The social life of things was both stuff or substance and its movements, formal foundation and the landscape of global cultural flow, in the manner characterized by Arjun Appadurai, material structure and the experimental empiricism of individual energies "where passions, opinions and attitudes bifurcated at every turn" (Latour 39).

Although a degree of confusion concerning sources has slipped into the secondary literature over the years, the collaborative provenance, or etymology, of a visual idea was clear to contemporaries. The many instrumental protagonists in a barter economy, and the self-consciousness with which such roles were executed, are still preserved in the era's firsthand reports. Unusually prolific Jesuit writers such as Luís Fróis, other scribes of official annual letters, and even casual correspondents leave enough clues for us to be able to ascertain the original flow of Western art as coming or requested from India (Goa, Kochi, Kolkata), China (Macau), and even as far off as Portugal (Lisbon). ${ }^{7}$ In Japan, the lord Dom Bartholomeo (né Ōmura Sumitada) indirectly cited the 
Portuguese trade route when he requested the Our Lady of Grace painting to which he had become so attached should another altarpiece arrive from India as a replacement; and this route was similarly cited for an image confiscated from a Portuguese transport ship to Hirado by the dreaded inspector Katō Kiyomasa in 1565. Fróis described the images intended for the Church at Ikitsuki in 1563 as coming from China, as were the very best altar ornaments for the Church at Yokoseura. Luís Almeida, S.J., even sent an ointment worth $100 \mathrm{cru}$ zados back to Lisbon to purchase a painting of Our Lady for the hospital at Bungo, so we know considerable trouble was expended to procure and transport art back East. And it was Queen Catarina of Portugal, wife of João III and sister to Emperor Charles V, who gave a small "painting of Jesus and Mary" to Dom Agostinho Konishi Settsu-no-kami Yukinaga, daimyo of Uto and admiral of Hideyoshi; he would lay it on his head three times in the traditional Japanese manner prior to surrendering to the death blow of the executioner, after falling into the hands of Ieyasu at the Battle of Sekigahara. And this short list does not include the occasional Italian object originating in Rome and transported to Lisbon for export.

Tracing the original sources alone does not account for how material agents were viewed and utilized to construct anew. For the Madonna of the Snow, perhaps the most salient, telling link is found in a series of Netherlandish engravings assembled in Japan to compose a Church Calendar (late sixteenth to early seventeenth century, engraving, Kobe City Museum). In this set, the months of January and February were mounted in reverse order, but most intriguing for this argument is the choice of the Assumption of the Virgin to represent the month of August in honor of her feast day on August 15. This suggests how artists could seize upon conflations of chance to occlude the iconographical slippage between the summer Marian celebrations of Assumption and the Madonna of the Snow, whose feast day was a mere ten days earlier (August 5). If the exigencies of generating this fascinating Madonna can be reasonably hypothesized, even more compelling still is how the Japanese convertartist touched brush to paper when the advancing tides of change were only a whisper. A Roman founding myth could be relocated to Nagasaki and retrofitted in keeping with Tenchi Hajimari no Koto (The Beginning of Heaven and 
Earth), the eighteenth-century record of a sixteenth-century oral tradition that captures how the Bible was expressed in an Iberian/Latin lexicon among the "Hidden Christians" (Kakure Kirishitan) of Japan (Whelan). In sampling several cultures, biblical stories were remixed for the contemporary Japanese situation, as exemplified by the crown of flowers from Mary's return to earth to aid persecuted Christians. This was the sheer fecundity of translation as transmission, described by Walter Benjamin as "the growth of the original, which completes itself in enlarging itself" (71-72). The great value of these objects as testimonies to the singular negotiations of mobile production has been obscured when so narrowly focused on their ability to approximate an otherworldly original.

The physics of this fractal network, absent of Euclidean regularities, was thus left utterly unpredictable and unaccountable when mediators, people and things alike, translated, adapted and distorted the meaning or elements they were intended to carry (Appadurai, Modernity 46). The voluminous activity of discrete, at times disguised cultural agents at play in the disport of things suggests the fertile soil of a history that focuses on accidents and shipwrecks over strict adherence to originality and successful communication. Gifts, perhaps the most entropic and capricious of conduits for cultural exchange, likewise ignited a range of painted imitation, unwittingly challenging the European print-after-painting model as Japanese nobles came to terms with Western geographic knowledge largely through printed media. The horizontal orientation of the World Map from Abraham Ortelius' Theatrum orbis terrarum (1570) could be recast for vertical formats, anchored by trading ships in the corners, Chinese and Japanese on top and Dutch and Portuguese below (late sixteenth to early seventeenth century, woodblock print on screen, Kobe City Museum, Mochizuki, "Moveable Center" 109-12). And despite reproducing this image's title, "Typus orbis terrarum," as arbitrary exotica for an audience unschooled in Latin, a pair of six-part map screens in Osaka brought the World into dialogue with a Map of Japan (late sixteenth to early seventeenth century, India ink, color and gold on paper, Osaka, Nanban Bunkakan, Mochizuki, "Moveable Center" 117-22). These were copies whose changes, or incidental piece-meal deconstruction of mimesis, were a highly conscious, intentional reformatting of information, unforeseeable and neither purely original nor a mistake per se. 
And nowhere is this seen more clearly than in the subtle shift of the Orteliusbased Osaka Map screens from a view of the World centered on Europe to one solidly usurped and embedded in Japan. Like the Madonna of the Snow, these were paintings that naturalized the frenetic kinesis of a manual agency in overdrive, objects whose competing, contradictory desires equally guaranteed that reactionary strategies of resistance could not be far behind.

\section{Casting Reception}

With the appropriation of geographic and cultural perspective, the last appearance of the Immaculate Conception, the distant cousin of João IV's Coin, is perhaps the most surprising and certainly the most tragic misunderstanding to derive from the movement of the printing press beyond Europe and into the political turmoil of religious encounter. Prints of the Immaculate Conception, and other religious subjects, were molded into fumi-e-flat, metal reliefs, often framed in wood (Fig. 5) - to be stepped on in the performance of apostasy when Christianity was finally explicitly outlawed in Japan, a ceremony practiced from circa 1624 through $1871 .{ }^{8}$ Inquisitors, under a new policy designed to eradicate Christianity (shümon aratame), would watch suspects carefully to detect the slightest tremor or hesitation when asked to step on the fumi-e panel, as body language-in other words iconoclasm manqué — signified loyalty to local leaders and religions alike. ${ }^{9}$ By inviting the respondent to engage physically with the object, to tread on the surface and feel the cool, bumpy relief underfoot, perhaps even imprint its message on the soul via the sole, the relief would be rubbed smooth by the passing of so many feet in a neat counterpart to the wear and tear of handshakes abrading coin and connection as imperial and evangelical paths were "refracted back to Europe according to local economies of power" (Barletta, "Message"). This was a genre that only encounter could bring into existence, when societal strictures were exercised and flexed to constrain the excesses of conflicting individual ambitions. Systemic checks for the visual culture of contact zones included not only the constrictions of transportation and distance, printing technology and mimesis, and the internal politics of Jesuit missionaries and Portuguese merchants, but also the obstacles that greeted the energies of agent and object in their theaters of conflict. Hand-to-hand battle is generally 


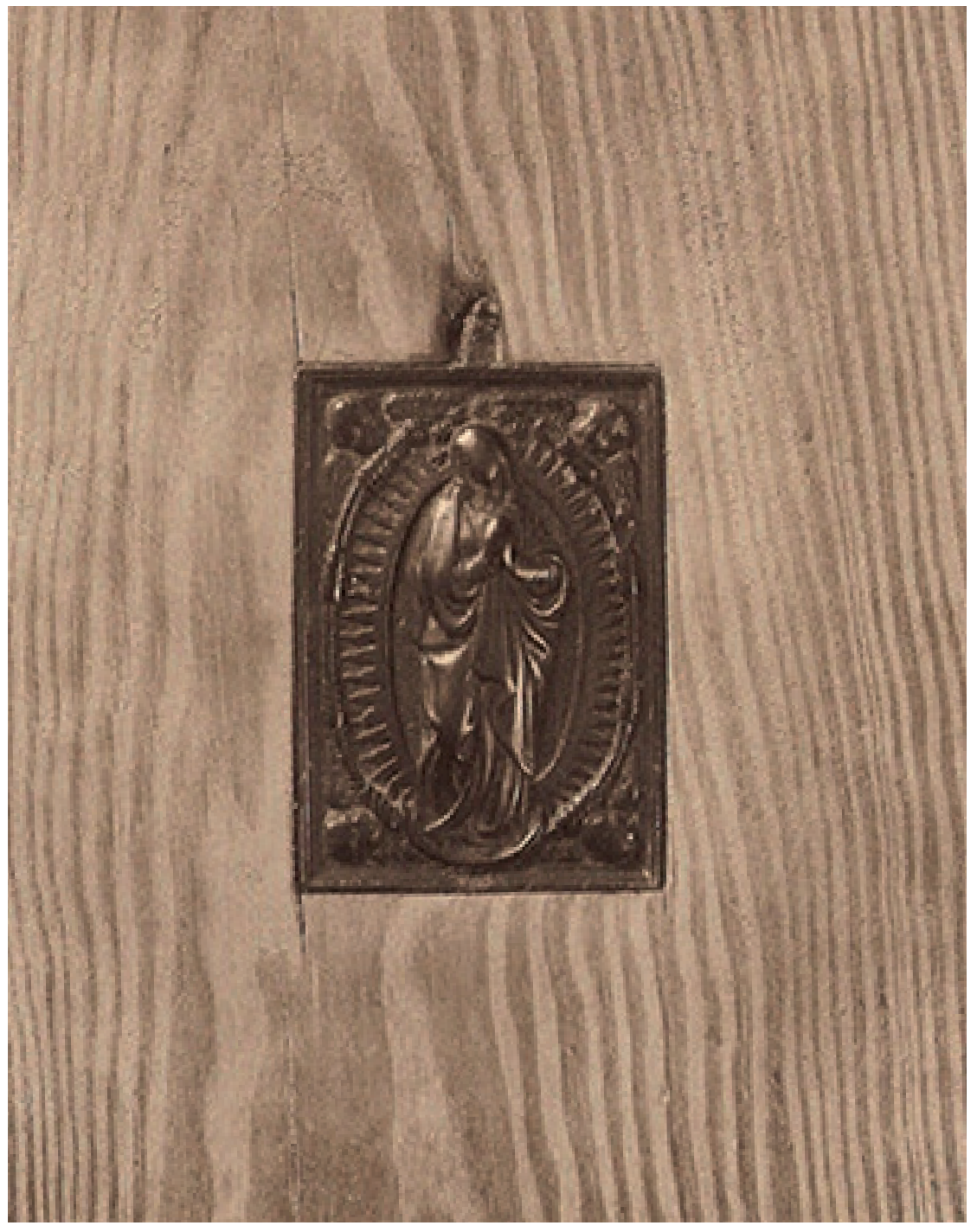

Fig. 5. Anonymous, Our Lady of the Immaculate Conception, late $16^{\text {th }}-17^{\text {th }}$ century, bronze in wood frame, Tokyo, National Museum (photo: TNM Image Archives) 
assumed to involve sword and shield, but it could also be joined by weapons of coin, print, statue, painting, and cast bronze relief that brooked disparate communities. The simulation of European copper plates made a mockery of both Christian subject matter and their method of visual argumentation. What had once proven to be a critical resource for the missionaries, the near-direct duplication of objects to initiate the analogous conversion of person, was re-directed to destroy, via martyrdom, the very people responsible for them. And the preponderance of scenes of suffering in this genre-Ecce Homo, the Crucifixion, and the Pietà-resolutely underscore the bitter taste of failure inherent in the tension between individual desires and structural controls that mimetic copying encountered overseas in the reception of early modern religious art (Kaufmann, "Interpreting;" Mochizuki, "Shock Value").

The global revolution of the Immaculate Conception Coin-from tracing its source to initiating a chain reaction of multiple concrete effects-found its most clear articulation since printed form in its antonym, its mimetic Other, a monstrously distorted double. The remaining plates of the Jesuit Press were pressed into service under pressure, and the whole story is told through a series of transmittals from impressions to press, pressing to pressure, and finally repression. "The Society is formed in persecution" ("Societas Iesu persecutionibus formatur"), reads the motto for a Jesuit emblem from Antwerp found on folio $571^{\mathrm{r}}$ in the Imago primi saeculi Societatis Iesu (1640). ${ }^{10}$ The emblem portrays a young man working on the mimetic repertoire of his press and even goes so far as to cite a short phrase from book six, line 80 of Virgil's Aeneid: "shaped by pressing" "fingitque premendo." Here we find a striking visual admission of a printing-press model of cultural dialogue that had lapsed under the pressure of adversity. By reconnecting European art history to the realities of the emerging world, mundus and the mundane, we would do well to remember that when mimetic religious copying confronted others outside Europe, the resulting material culture of contact zones was conditional, not fixed, and more often than not premised on a lack of communication. This was not, however, a purely negative phenomenon. Miscommunication and even flat out repudiation were just as much formative impulses for early modern pictorial and personal encounter as the Platonic appeal of harmonious discourse. Although 
seemingly counter-intuitive, an argument could be made for embracing the haphazard arbitrariness of early modern maritime commerce, akin to Peter Burke's theory of "creative misinterpretation" (28) and Marshall Sahlins' evidence of cultures mutually misconstruing one another, whether intentionally or not, rather than smoothing distinctions into the logic of sameness, what Leo Steinberg has called "homeosis" (Kaufmann, Toward 17-104; Steinberg 100).

In closing, one of the most challenging aspects of analyzing the networks that bound the early modern world is encompassing the sheer magnitude of the scope of study. Perhaps the most productive approach, not to mention a well-grounded way to prevail over the macro- and micro-history divide, has been to press ever so gently on the concept's fault lines, be they the irony of knowing the global through the local, the conceptual through the material, or the tension between individual agency and its structural constraints. When the Portuguese naus took to the high seas, the fertile interpretive potential of the worlding of an idea through touch was stressed, and we are left to hunt for the fingerprint stowaways that shaped a truly global Republic of Things. Far beyond what the waves of missiological imprinting, be it of person or thing, could possibly have predicted, porous Portugal and its Luso-Exchange engineered a mobile imaginary that had to contend with compounded receptions, at distances only barely fathomable, and a cast of characters and armatures of resistance that inhabited such faraway cultural nodes. Ultimately, these excerpts from interludes of tangible interactions argue for a reconsideration of the value of thinghood and the lives of objects that are foregrounded against the restrictive reception to iconography on the global stage. They are hand-held reminders of how form, content, and thing acted and reacted to "only connect" material thoughts. The active responses sparked by mimesis over its appearance alone can pave the way for a hermeneutic of cultural exchange as misinterpretation, the contingency of contact. And it very likely brings us closer to what actually happened, lest in our desire for seamless resolutions and happy endings, we ignore the limitations of the mimetic tradition the printing press telegraphed to the world and inadvertently let wishful thinking leave us insensate and woefully, literally, out of touch. 


\section{Notes}

1 For an account of the ominous classical undertones associated with this process of "showing new worlds to the world" by the Portuguese, see Barletta, Death in Babylon.

2 See Leeflang 18: 2, 72-80; Leesberg and Balis 16: 3, 96-99; Van der Stock and Leesberg 62: 4, 234-39; 63: 5, 7-25.

3 See Morna 30-31; Oliveira, Morna, Simões, and Lino 117-18; Oliveira, Morna, Ferreira, and Requixa 190; Távora 37.

4 See Carvalho and Franco 133-44, 364-69; Lowe; Smith 201; Serrão 179-82.

5 See Markl, "Duas novas obras," "Duas gravuras;" Sobral; Serrão 182-97.

6 Our Lady of the Immaculate Conception was not listed as part of the Jesuit goods that entered the collection of the Santa Casa Misericórdia de Lisboa/Museu de São Roque in 1768, following the suppression of the Society, but inventories record its presence in the collection by 1900 (Lisbon, Arquivo Histórico, Igreja de São Roque IG\GF\02\Lv010A; Lisbon, Arquivo do Tribunal de Contas ff. 23-73).

7 See Fróis, S.J. 157, 159, 162, 189, 242, 267, 308; García Gutiérrez, S.J. 176; Schurhammer, S.J., Gesammelte Studien 1: 4, 6; 2: 769-70; 4: 124; Schurhammer, S.J., Francis Xavier 62.

8 See Kataoka 27; Matsuda 12: 332-33; Koschorke, Ludwig, and Delgado 32-33; Okada 160-61; Schurhammer, Gesammelte Studien 4: 177-78.

9 See Elison 204; Kaufmann, Toward 303-40; Mochizuki, "Deciphering the Dutch;" Shimada and Shimada.

10 See Bollandus, S.J., et al., Af-Beeldinghe f. 398r; Dekoninck, Ad Imaginem 203-05, fig. 18; "La Passion" 54-56. 


\section{Works Cited}

Primary Sources

Lisbon, Arquivo Histórico, Igreja de São Roque. Gestão Financeira, Inventários da Igreja de São Roque e anexos (1900). Santa Casa Misericórdia de Lisboa\IG\GF\02\Lv010A.

Lisbon, Arquivo do Tribunal de Contas. Cartório da Junta da Inconfidência, Companhia de Jesus, Casa Professa de São Roque-Lisboa, maço 29, n. 112, doc. 5, ff. 23-73.

Secondary Sources

D’Alcocheyte, Nuno Daupiás. "L’oficina Craesbeckiana de Lisbonne." Arquivos do Centro Cultural Português da Fundação Calouste Gulbenkian 9 (1975): 601-37. Print.

Alden, Dauril. The Making of an Enterprise: The Society of Jesus in Portugal, Its Empire and Beyond, 1540-1750. Stanford, CA: Stanford UP, 1996. Print.

Almeida, Justino Mendes de. "Propagation of the Portuguese Language through Missionary Work." Encounter of Cultures: Eight Centuries of Portuguese Mission Work. Ed. Maria Isabel Rocha Roque. Lisbon: Printing Portuguesa, 1996. 222-26. Print.

Appadurai, Arjun. Modernity at Large: Cultural Dimensions of Globalization. Minneapolis: U of Minnesota P, 1996. Print.

—. ed. The Social Life of Things. Commodities in Cultural Perspective. Cambridge: Cambridge UP, 1986. Print.

Arberry, Arthur John. Tales from the Masnavi. Surrey: Curzon, 1993. Print.

Barletta, Vincent. Death in Babylon. Alexander the Great and Iberian Empire in the Muslim Orient. Chicago: U of Chicago P, 2010. Print.

—. Message to the author. 10 Jan. 2014. E-mail.

Baxandall, Michael. Painting and Experience in Fifteenth-Century Italy: A Primer in the Social History of Pictorial Style. Oxford: Oxford UP, 1972. Print.

Benjamin, Walter. "The Task of the Translator. An Introduction to the Translation of Baudelaire's Tableaux Parisiens." Illuminations. Ed. Hannah Arendt. Trans. Harry Zohn. New York: Schocken, 1968. 69-82. Print.

Bollandus, Joannes, S.J., et al. Af-Beeldinghe van deerste eeuwe der Societeyt Iesu voor ooghen ghestelt door de Duyts-Nederlantsche Provincie der selver Societeyt. Trans. Adrianus Poirters, S.J. and Laurentius Uwens, S.J. Antwerp: Plantin 1640. Print.

_. Imago primi saeculi Societatis Iesu, a Provincia Flandro-Belgica eiusdem Societatis repraesentata. Antwerp: Moretus, 1640. Print.

Born, Annick, and Maximiliaan P.J. Martens. "O políptico de Quinten de Metsys para o Convento da Madre de Deus: Notas sobre a técnica." Casa Perfeitíssima: 500 Anos da fundação do Mosteiro da Madre de Deus / Celebrating 500 Years of the Foundation of the Convent of Madre de Deus, 1509-2009. Ed. Alexandra Curvelo. Lisbon: Instituto dos Museus e da Conservação, 2009. 155-165, 373-77. Print.

Burke, Peter. The Renaissance. New York: St. Martin's, 1987. Print.

Camões, Luís Vaz de. Os Lusíadas. Ed. Emanuel Paulo Ramos. Porto: Porto Editora, 2006. Print. 
Carvalho, Maria João Vilhena de, and Anísio Franco. "Os Della Robbia da Rainha D. Leonor: Imagens florentinas do Mosteiro da Madre de Deus de Lisboa." in Casa Perfeitíssima: 500 Anos da fundação do Mosteiro da Madre de Deus / Celebrating 500 Years of the Foundation of the Convent of Madre de Deus, 1509-2009. Ed. Alexandra Curvelo. Lisbon: Instituto dos Museus e da Conservação, 2009. 133-44, 364-69. Print.

Dalwood, Dexter, et al. "Mimesis." Art Bulletin 95 (June 2013): 190-211. Print.

David, S.J., Jan. Veridicus christianus. Antwerp: Plantin, 1601. Print.

Dekoninck, Ralph. Ad Imaginem: Status, fonctions, et usages de l'image dans la littérature spirituelle jésuite du XVIIe siècle. Geneva: Droz, 2005. Print.

"La Passion des images: La traversée des images jésuites entre Ancien et Nouveau Monde." De zeventiende eeuw 21.1 (2005): 49-63. Print.

Dias, Pedro. "A influência da escultura nórdica na escultura portuguesa da Época Manuelina." Da Flandres e do Oriente. Escultura Importada. Colecção Miguel Pinto. Ed. Alexandra Curvelo, Maria Antónia Pinto da Matos, and Maria João Vilhena de Carvalho. Lisbon: Casa Museu Anastácio Gonçalves, 2002. 22-39. Print.

—. História da Arte Portuguesa no Mundo (1415-1822). 2 vols. Lisbon: Círculo de Leitores, 1998. Print.

Elison, George. Deus Destroyed: The Image of Christianity in Early Modern Japan. Cambridge, MA: Harvard UP, 1973. Print.

Fróis, Luís, S.J. Die Geschichte Japans (1549-1578). Trans and Ed. Georg Schurhammer, S.J. and E.A. Voretzsch. Leipzig: Verlag der Asia Minor, 1926. Print.

García Gutiérrez, S.J., Fernando. "Valignano and the Introduction of Western Art to Japan." Alessandro Valignano S.I.: Uomo del Rinascimento, ponte tra Oriente e Occidente. Ed. Adolfo Tamburello, M. Antoni J. Üçerler, S.J., and Marisa di Russo. Rome: Institutum Historicum Societatis Iesu, 2008. 175-83. Print.

Gijsen, Marnix (Jan Albert Goris). Étude sur les colonies marchandes méridionales (portugais, espagnols, italiens) à Anvers de 1488 à 1567: Contribution à lhistoire des débuts $d u$ capitalisme moderne. Louvain: Librarie Universitaire, 1925. Print.

Góis, Damião de. Chronica d’el rei D. Manuel. 1566. Lisbon: Mello d’Azevedo, 1910. Print.

—. Fides, religio, moresque Aethiopum sub Imperio Preciosi Ioannis. Louvain: Rescius, 1540. Print.

Greenblatt, Stephen. Marvelous Possessions: The Wonder of the New World. Chicago: U of Chicago P, 1991. Print.

__. "A Mobility Studies Manifesto." Cultural Mobility: A Manifesto. Ed. Stephen Greenblatt. Cambridge: Cambridge UP, 2009. 250-53. Print.

Greene, Roland. Five Words: Critical Semantics in the Age of Shakespeare and Cervantes. Chicago: U of Chicago P, 2013. Print.

Huylebrouck, Rosa. "Alguns documentos comerciais lusoflamengos do século XVII com interesse para a História de Arte." Revista da Faculdade de Letras do Porto 7 (1990): 281-97. Print.

Kataoka, Yakichi. Fumie: kinkyō no rekishi. Tokyo: Nihon Hōsō Shuppan Kyōkai, 1977. Print.

Kaufmann, Thomas DaCosta. "Interpreting Cultural Transfer and the Consequences of Markets and Exchange: Reconsidering Fumi-e." Artistic and Cultural Exchanges between Europe and Asia, 1400-1900: Rethinking Markets, Workshops and Collections. Ed. Michael North. Aldershot, UK: Ashgate, 2010. 135-61. Print. 
Toward a Geography of Art. Chicago: U of Chicago P, 2004. Print.

Kinoshita, Sharon. "Reorientations: The Worlding of Marco Polo." Cosmopolitanism and the Middle Ages. Ed. John M. Ganim and Shayne Aaron Legassie. New York: Palgrave Macmillan, 2013. 39-57. Print.

Koschorke, Klaus, Frieder Ludwig, and Mariano Delgado, eds. A History of Christianity in Asia, Africa, and Latin America, 1450-1990: A Documentary Sourcebook. Grand Rapids, MI: Eerdmans, 2007. Print.

Latour, Bruno. Reassembling the Social: An Introduction to Actor-Network-Theory. Oxford: Oxford UP, 2005. Print.

Leeflang, Huigen, ed. The New Hollstein Dutch and Flemish Etchings, Engravings and Woodcuts, 1450-1700. Johannes Stradanus. Vol. 18: 2. Ouderkerk aan den IJssel: Sound \& Vision, 2008. Print.

Leesberg, Marjolein, and Arnout Balis, eds. The New Hollstein Dutch and Flemish Etchings, Engravings and Woodcuts, 1450-1700. The Collaert Dynasty. Vol. 16: 3. Ouderkerk aan den IJssel: Sound \& Vision, 2005. Print.

Levenson, Jay A., ed. Encompassing the Globe. Portugal and the World in the 16th and 17th Centuries. Washington, D.C.: Smithsonian Institution, 2007. Print.

Lowe, K.J.P., ed., Cultural Links between Portugal and Italy in the Renaissance. Oxford: Oxford UP, 2000. Print.

Markl, Dagoberto L. "Lart dans la défense de Damião de Góis: Son goût et sa collection." Portugal et Flandre: Visions de l'Europe (1550-1680). Brussels: Fondation Europalia International, 1991. 192-95. Print.

"Duas gravuras de Albrecht Dürer no painel 'Jesus em casa de Marta e Maria' atribuído a Vasco Fernandes: Breve achega ao estudo da influência alemã na pintura portuguesa do século XVI." História e Sociedade 4.5 (1979): 15-19. Print.

__ "Duas novas obras de Fernão Gomes." Boletim Cultural da Assembleia Distrital de Lisboa 86.2 (1980): 5-39. Print.

Martens, Maximiliaan P.J. “Antwerp Painters: Their Market and Networks." Jaarboek van het Koninklijk Museum voor Schone Kunsten Antwerpen (2004-2005): 47-73. Print.

Matsuda, Kiichi. "Fumi-e." Kokushi Daijiten. 15 vols. Tokyo: Yoshikawa Kōbunkan, 1979-1997. 12: 332-33. Print.

Mochizuki, Mia M. "Deciphering the Dutch in Deshima." Boundaries and Their Meanings in the History of the Netherlands. Ed. Benjamin Kaplan, Marybeth Carlson, and Laura Cruz. Leiden: Brill, 2009. 63-94. Print.

"Seductress of Site: The Nagasaki Madonna of the Snow." Aemulatio: Imitation, Emulation and Invention in Netherlandish Art 1500 to 1800: Essays in Honor of Eric Jan Sluijter. Ed. Anton W.A. Boschloo, Jacquelyn N. Coutré, Stephanie S. Dickey, and Nicolette C. Sluijter-Seijffert. Zwolle: Waanders, 2011. 76-88. Print.

"Shock Value: The Jesuit Martyrs of Japan and the Ethics of Sight." Sensational Religion: Sense and Contention in Material Practice. Ed. Sally M. Promey. New Haven, CT: Yale UP, 2014. 375-97. Print.

"The Diaspora of a Jesuit Press: Mimetic Imitation on the World Stage." Crosscurrents in Illustrated Religious Texts in the North of Europe, 1500-1800. Ed. Feike Dietz, Adam 
Morton, Lien Roggen, Els Stronks and Marc Van Vaeck. Farnham, UK: Ashgate, 2014. Forthcoming. Print.

. "The Movable Center: The Netherlandish Map in Japan." Artistic and Cultural Exchanges between Europe and Asia, 1400-1900: Rethinking Markets, Workshops and Collections. Ed. Michael North. Aldershot, UK: Ashgate, 2010. 109-33. Print.

Morna, Teresa Freitas. "Nossa Senhora da Conceição." No Caminho do Japão: Arte Oriental nas Colecções da Santa Casa da Misericórdia de Lisboa. Ed. Nuno Vassallo e Silva, Maria Filomena Brito, and Teresa Freitas Morna. Lisbon: Santa Casa da Misericórdia de Lisboa, 1993. 30-31. Print.

Nancy, Jean-Luc. The Creation of the World or Globalization. Trans. François Raffoul and David Pettigrew. Albany, NY: State U of New York P, 2007. Print.

Norman, Donald A. The Psychology of Everyday Things. New York: Basic, 1988. Print.

Okada, Akio. "Fumi-e ni tsuite." Kirishitan kenkyū 2 (1944): 149-83. Print.

Oliveira, Maria Helena, Teresa Freitas Morna, João Miguel Simões, and Maria do Carmo Lino, eds. Arte Oriental nas Colecções do Museu de São Roque. Lisbon: Santa Casa da Misericórdia de Lisboa, 2010. Print.

Oliveira, Maria Helena, Teresa Freitas Morna, Maria João Ferreira, and Maria Madalena Requixa, eds. Museum of São Roque. Trans. Thomas E. Fisher. Lisbon: Santa Casa da Misericórdia de Lisboa, 2008. Print.

Ortelius, Abraham. Theatrum orbis terrarum. Antwerp: Gilles Coppens van Diest, 1570. Print.

Peixoto, Jorge. Relações de Plantin com Portugal: notas para o estudo da tipografia no século XVI. Coimbra: Faculdade de Letras, 1962. Print.

Réau, Louis. Iconographie de l'art chrétien. 6 vols. Paris: Presses Universitaires de France, 195559. Print.

Riegl, Alois. Late Roman Art Industry. Trans. Rolf Winkes. Rome, Giorgio Bretschneider, 1985. Print. Trans. of Spätromische Kunstindustrie. Vienna: Österreichische Staatsdruckerei, 1927. Print.

—. Problems of Style: Foundations for a History of Ornament. Trans. E.M. Kain. Princeton: Princeton UP, 1992. Print. Trans. of Stilfragen: Grundlegungen zu einer Geschichte der Ornamentik. Berlin: Schmidt, 1923. Print.

Riles, Annelise. The Network Inside Out. Ann Arbor, MI: U of Michigan P, 2001. Print.

Sahlins, Marshall. Islands of History. Chicago: U of Chicago P, 1985. Print.

Schurhammer, S.J., Georg. Francis Xavier: His Life, His Times. Vol. IV: Japan and China, 15491552. Trans. M. Joseph Costelloe, S.J. Rome: Institutum Historicum Societatis Iesu, 1982. Print.

—. Gesammelte Studien. Vol. 1: Die zeitgenössischen Quellen zur Geschichte PortuguiesischAsiens und seiner Nachbarländer... zur Zeit des hl. Franz Xaver, 1538-1552. Rome: Institutum Historicum Societatis Iesu, 1962. Print.

—. Gesammelte Studien. Vol. 2: Orientalia. Rome: Institutum Historicum Societatis Iesu, 1963. Print.

—. Gesammelte Studien. Vol. 4: Varia. Rome: Institutum Historicum Societatis Iesu, 1965. Print.

Serrão, Vitor. A pintura protobarroca em Portugal, 1612-1657: o triunfo do naturalismo e do tenebrismo. Lisbon: Colibri, 2000. Print. 
Shearman, John K.G. Only Connect... Art and the Spectator in the Italian Renaissance. Princeton, NJ: Princeton UP, 1992. Print.

Shimada, Takau, and Yuriko Shimada. Fumie: gaikokujin ni yoru fumie no kiroku. Tokyo: Yūshōdō Shuppan, 1994. Print.

Smith, Robert C. The Art of Portugal 1500-1800. New York: Meredith, 1968. Print.

Sobral, Luís de Moura. "L'estampe anversoise et la peinture portugaise au début du XVIIe siècle: Le Missel pontifical de Gonçalves Neto." Portugal et Flandre: Visions de l'Europe (1550-1680). Brussels: Fondation Europalia International, 1991. 56-67. Print.

Steinberg, Leo. “An Incomparable Bathsheba." Rembrandt's Bathsheba Reading King David's Letter. Ed. Ann Jensen Adams. Cambridge: Cambridge UP, 1998. 100-18. Print.

Stock, Jan van der, and Marjolein Leesburg, eds. Hollstein's Dutch and Flemish Etchings, Engravings and Woodcuts, 1450-1700. The Wierix Family. Vol. 62: 4. Rotterdam: Sound \& Vision, 2003. Print.

—, eds. Hollstein's Dutch and Flemish Etchings, Engravings and Woodcuts, 1450-1700. The Wierix Family. Vol. 63: 5. Rotterdam: Sound \& Vision, 2004. Print.

Taussig, Michael. Mimesis and Alterity: A Particular History of the Senses. London: Routledge, 1993. Print.

Távora, Bernardo Ferrão de Tavares e. Imaginária Luso-Oriental. Lisbon: Imprensa NacionalCasa da Moeda, 1983. Print.

Virgil. Eclogues, Georgics, Aeneid, Books 1-6. Trans. H.R. Fairclough. Cambridge, MA: Harvard UP, 2001. Print.

Whelan, Christal. The Beginning of Heaven and Earth: The Sacred Book of Japan's Hidden Christians. Honolulu: U of Hawai'i P, 1996. Print. 
Mia M. Mochizuki is Associate Professor of the History of Art at New York University Abu Dhabi and the Institute of Fine Arts, New York. Her interdisciplinary research has addressed problems in Renaissance, Reformation (Catholic and Protestant), and Baroque art, with particular attention to the trade networks that situate European visual culture in a broader world context. She is the author of The Netherlandish Image after Iconoclasm, 1566-1672: Material Religion in the Dutch Golden Age (2008), which received the College Art Association Publication Award and the ACE/Mercers' International Book Award for Religious Art and Architecture, and the editor of In His Milieu: Essays on Netherlandish Art in Memory of John Michael Montias (2006) on the archival and socio-economic study of art. Her next book, The Jesuit Global Baroque, is forthcoming. 